\title{
Periodicals in college libraries: Are the challenges of rising subscription costs being met?
}

\author{
By Thomas G. Kirk \\ College Librarian \\ Berea College
}

1

he survey results reported here were part of a presentation at a conference on "Serials: Problems and Prospects" sponsored by the College of Library and Information Science at the University of Kentucky held in February 1990. The author's experience with periodicals in college libraries suggested that the problems which smaller predominantly undergraduate institutions face are different than those of larger universities which serve graduate students and a large community of research faculty. ${ }^{1}$ Specifically, the author believed that the escalating costs of serials which confront

\section{... the author believed that the escalating costs of serials which confront the research libraries have not been as significant an issue for college libraries.}

the research libraries ${ }^{2}$ have not been as significant an issue for college libraries. To get some sense of the place of periodicals in college library budgets and collections, the author collected data from existing sources and through a survey designed to collect supplemental data.

Initially a search of the literature was performed to seek information on the status of periodicals in college libraries. The results of the search were a limited number of articles that dealt with such issues as the history of the Associated Colleges of the Midwest's periodical bank, ${ }^{3}$ the selection of titles as part of collection development, ${ }^{4}$ measurement of periodicals use ${ }^{5}$ and the substitution of online services and document delivery/interlibrary loan for ownership of periodicals and periodical indexes. ${ }^{6}$ However, no literature was found on the changing status of periodicals in college libraries.
Given the dearth of literature and the author's desire to have some sense of whether his assumptions were correct, plans were developed for a survey. Annual data from about 30 college libraries had been gathered over at least the last 15 years and about ten years ago the same data gathering was expanded to include about 20 additional college libraries. Since this well-established body of unpublished data already exists, the data elements of that survey were used as the basis for constructing the survey questionnaire used in this study.

The survey was sent in January 1990 to libraries in the base group of 53 colleges to obtain data not in the original annual survey results. In some cases the data, especially that from earlier years, could not be provided. These 53 colleges represent all sections of the United States but, because the institutions are highly selective in their student admissions, it was not expected that this group would represent college libraries generally. In order to broaden the scope of the survey group, the survey was sent in Febnuary 1990 to 21 private colleges in a southeastern state. Fourteen institutions or $67 \%$ of the institutions responded. This group included two-year as well as four-year institutions. Table 1 reports information on the sizes of the student body and faculty.

A summary of the questionnaire data is presented here in tables 2 and 3. In order to simplify the data, only a single fiscal year of data at five-year intervals was collected and presented. The years were selected by starting with the most recent year for which data was available, 1988/89, and counting back five years (1983/84), ten years (1978/79), and 15 years $(1973 / 74)$. The absence of data in the earlier years is due largely to the fact that institutions did not keep such information.

For each of the four years the data includes the lowest and highest reported levels (e.g., the range or spread of the data), and the mean and median for the reporting group of institutions. For categories which 
Table 2: INTERLIBRARY LOAN DATA

\begin{tabular}{|c|c|c|c|c|c|c|}
\hline Years & $\begin{array}{l}\text { Undergrad. } \\
\text { enrollment }\end{array}$ & $\begin{array}{c}\text { Number of } \\
\text { faculty }\end{array}$ & $\begin{array}{c}\text { ILLs } \\
\text { borrowed }\end{array}$ & $\begin{array}{l}\text { ILLs } \\
\text { lent }\end{array}$ & $\begin{array}{l}\text { ILL req. } \\
\text { per fac. }\end{array}$ & $\begin{array}{l}\text { ILL req. } \\
\text { per stud. }\end{array}$ \\
\hline \multicolumn{7}{|l|}{ 1973-1974 } \\
\hline Lowest level reported & 130 & 12 & 0 & 0 & 0 & 0 \\
\hline Highest level reported & 3,030 & 280 & 3,869 & 2,998 & 47 & 4 \\
\hline Mean & 1,358 & 109 & 1,006 & 810 & 9 & 1 \\
\hline Median & 1,227 & 97 & 824 & 517 & 6 & 0 \\
\hline \multicolumn{7}{|l|}{ 1978-1979 } \\
\hline Lowest level reported & 214 & 16 & 0 & 0 & 0 & 0 \\
\hline Highest level reported & 3,093 & 278 & 5,313 & 4,932 & 46 & 4 \\
\hline Mean & 1,471 & 116 & 1,250 & 1,051 & 11 & 1 \\
\hline Median & 1,473 & 108 & 857 & 661 & 8 & 1 \\
\hline \multicolumn{7}{|l|}{ 1983-1984 } \\
\hline Lowest level reported & 268 & 20 & 31 & 7 & 0 & 0 \\
\hline Highest level reported & 3,263 & 297 & 5,996 & 8,760 & 46 & 4 \\
\hline Mean & 1,459 & 131 & 1,899 & 1,574 & 14 & 1 \\
\hline Median & 1,396 & 123 & 1,411 & 1,192 & 10 & 1 \\
\hline \multicolumn{7}{|l|}{ 1988-1989 } \\
\hline Lowest level reported & 189 & 18 & 0 & 0 & 0 & 0 \\
\hline Highest level reported & 3,443 & 341 & 8,977 & 6,738 & 69 & 6 \\
\hline Mean & 1,509 & 134 & 2,514 & 2,228 & 18 & 2 \\
\hline Median & 1,496 & 118 & 2,198 & 1,952 & 16 & 2 \\
\hline \multicolumn{7}{|c|}{ Change between 1973-1974 and 1988-1989 } \\
\hline Lowest level reported & 59 & 6 & 0 & 0 & 0 & 0 \\
\hline Highest level reported & 413 & 61 & 5,108 & 3,740 & 22 & 2 \\
\hline Mean & 151 & 25 & 1,508 & 1,418 & 9 & 1 \\
\hline Median & 269 & 22 & 1,574 & 1,435 & 10 & 1 \\
\hline
\end{tabular}

are calculations (e.g., \% materials is of total budget), the values are based on the values for the individual institutions rather than the values reported on the same row of the table. For example, the value $13.01 \%$ represents the "\% materials is of total budget," is the lowest reported by an individual institution rather than the result of the calculation $\$ 1,422 \$ 9,275$. This approach was used because on any of the lines reporting the lowest or highest level the figures are not necessarily from the same institution. The same procedure was used for the lines reporting mean and median in order to maintain consistency.

At the bottom of the tables the level of change is reported between 1973/74 and 1988/89.

The survey data illustrate several important trends in periodicals in this sample of college libraries. First, the materials budget as a percentage of the total library budget has not changed significantly between $1973 / 74$ and $1988 / 89$. This suggests that pressure on budgets from rising periodical costs did not force libraries to reduce the growth rate of their salary and operating budgets.

Second, the percentage of the materials budget spent on periodicals has increased from a mean of $31 \%$ in $1973 / 74$ to $42 \%$ in $1988 / 89$. However, most of the shift, $31 \%$ to $38 \%$, occurred in the five-year period $1973 / 74$ to $1978 / 79$. Since $1978 / 79$ the shift has been only $4 \%$ from $38 \%$ to $42 \%$. Therefore, during the last ten years, while periodical prices have been growing most rapidly, college libraries have made some shifts in the allocation of materials budgets, but the shifts have not been substantial.

A third conclusion that can be reached from this summary data is that college libraries have increased the number of subscriptions over the last 15 years. The average number of titles has gone from 
Table 3: PERIODICALS IN COLLEGE LIBRARIES: FINANCIAL DATA

\begin{tabular}{|c|c|c|c|c|c|c|c|c|c|}
\hline & $\begin{array}{l}\text { Total library } \\
\text { expenditures }\end{array}$ & $\begin{array}{c}\text { Total materials } \\
\text { expenditures }\end{array}$ & $\begin{array}{c}\mathscr{W} \text { materials } \\
\text { is of total } \\
\text { budget }\end{array}$ & $\begin{array}{c}\text { Periodicals } \\
\text { expenditures }\end{array}$ & $\begin{array}{l}\% \text { penod. is } \\
\text { of materials } \\
\text { expenditure }\end{array}$ & $\begin{array}{c}\text { Number } \\
\text { periodical } \\
\text { titles recejved }\end{array}$ & $\begin{array}{c}\text { Avg price } \\
\text { per title }\end{array}$ & $\begin{array}{l}\text { Periodical } \\
\text { expenditures } \\
\text { per faculty }\end{array}$ & $\begin{array}{l}\text { Periodical } \\
\text { expenditures } \\
\text { per student }\end{array}$ \\
\hline \multicolumn{10}{|l|}{$1973-1974$} \\
\hline Lowest level reported & $\$ 9.275$ & $\$ 1.422$ & $13.01 \%$ & $\$ 3,890$ & $15.30 \%$ & 233 & $\$ 9.40$ & $\$ 63.25$ & $\$ 8.44$ \\
\hline Highest level reported & $\$ 918.471$ & $\$ 310,000$ & $77.27 \%$ & $\$ 103,622$ & $4806 \%$ & 2,800 & $\$ 5343$ & $\$ 683.56$ & $\$ 48.22$ \\
\hline Mean & $\$ 306,504$ & $\$ 110,640$ & $36.80 \%$ & $\$ 32,268$ & $31.13 \%$ & 1,224 & $\$ 26.77$ & $\$ 294.10$ & $\$ 23.12$ \\
\hline Median & $\$ 290,041$ & $\$ 104,900$ & $36.15 \%$ & $\$ 29,011$ & $30,30 \%$ & 1,149 & $\$ 26.62$ & $\$ 271.59$ & $\$ 20.32$ \\
\hline \multicolumn{10}{|l|}{ 1978-1979 } \\
\hline Lowest level reported & $\$ 22,156$ & $\$ 3,510$ & $12.10 \%$ & 83,254 & $19.46 \%$ & 227 & $\$ 13.89$ & $\$ 98.85$ & 87.37 \\
\hline Highest level reported & $\$ 1,438,538$ & $\$ 496,397$ & $52.24 \%$ & $\$ 309,000$ & $99.31 \%$ & 5,490 & $\$ 126.12$ & $\$ 1,707.18$ & $\$ 24960$ \\
\hline Mean & $\$ 464,726$ & $\$ 172,840$ & $35.70 \%$ & $\$ 63,410$ & $37.93 \%$ & 1.364 & $\$ 45.17$ & $\$ 526.13$ & $\$ 43.12$ \\
\hline Median & $\$ 422,688$ & $\$ 163,682$ & $36.99 \%$ & 548,029 & $36.47 \%$ & 1,217 & $\$ 42.91$ & $\$ 457.20$ & $\$ 35.57$ \\
\hline \multicolumn{10}{|l|}{ 1983-1984 } \\
\hline Lowest level reported & $\$ 29,440$ & $\$ 4,952$ & $16.82 \%$ & 82,542 & $19.25 \%$ & 128 & $\$ 17.69$ & \$.110.52 & $\$ 5.88$ \\
\hline Highest level reported & $\$ 2,230,660$ & $\$ 802,844$ & $52.15 \%$ & $\$ 392,615$ & $54.39 \%$ & 3,941 & $\$ 130.84$ & $\$ 7,158.56$ & $\$ 172.20$ \\
\hline Mean & $\$ 771.524$ & $\$ 288,737$ & $35.35 \%$ & $\$ 112.944$ & $38.17 \%$ & 1.406 & $\$ 72.83$ & $\$ 858.14$ & $s 71.48$ \\
\hline Median & $\$ 721,382$ & $\$ 267,020$ & $35.51 \%$ & $\$ 90,470$ & $37.69 \%$ & 1,228 & 873.39 & $\$ 765.77$ & $\$ 67.88$ \\
\hline \multicolumn{10}{|l|}{$1988-1989$} \\
\hline Lowest level reported & $\$ 40.253$ & $\$ 5,043$ & $12.53 \%$ & 81,405 & $18.26 \%$ & 41 & $\$ 10.56$ & $\$ 78.06$ & $\$ 7.43$ \\
\hline Highest level reported & $83,330,771$ & $\$ 1,046,385$ & $49.79 \%$ & $\$ 579,215$ & $74.44 \%$ & 4,449 & $\$ 214.21$ & $\$ 2,726,74$ & $\$ 25448$ \\
\hline Mein & $\$ 1,131,837$ & $\$ 415,278$ & $35.78 \%$ & $\$ 186,538$ & $42.12 \%$ & 1,535 & $\$ 105.72$ & $\$ 1.232 .26$ & $\$ 11110$ \\
\hline Median & $\$ 1,018,510$ & $\$ 3554,015$ & $35.76 \%$ & 8155,476 & $41.20 \%$ & 1,350 & $\$ 109.8 t$ & $\$ 1,112.88$ & $\$ 9765$ \\
\hline \multicolumn{10}{|c|}{ Change between 1973-74 and 1988-89 } \\
\hline Lowest level reported & $\$ 30,978$ & $\$ 3,621$ & $.0 .48 \%$ & $(\$ 2,485)$ & $2.97 \%$ & -192 & $\$ 1.16$ & $\$ 14.80$ & $(\$ 1.01)$ \\
\hline Highest level reported & $\$ 2.412 .300$ & $\$ 736,385$ & $-27.47 \%$ & $\$ 475.593$ & $26.38 \%$ & 1,649 & $\$ 160.78$ & $\$ 2,043.18$ & $\$ 206.26$ \\
\hline Mean & $\$ 825,333$ & 8304,638 & $-1.01 \%$ & $\$ 154,269$ & $10.99 \%$ & 311 & $\$ 78.94$ & $\$ 938.17$ & $\$ 87.98$ \\
\hline Median & $\$ 728,469$ & $\$ 249,115$ & $.0 .38 \%$ & $\$ 126,465$ & $10.90 \%$ & 202 & $\$ 83.25$ & $\$ 841.28$ & $\$ 77.33$ \\
\hline
\end{tabular}


a mean of 1,224 to 1,535 which is a $25 \%$ increase. At the same time the average annual subscription rate for titles beld in the libraries increased from approximately $\$ 26.77$ to $\$ 105.72$, a $295 \%$ increase. This is an annual rate of increase of $19.7 \%$ over the 15 -year period from $1973 / 74$ to $1988 / 89$. However, this should not be construed as an inflation rate for periodicals in college libraries since the list of titles was not constant over the 15 years.

Another set of conclusions centers around the relationship between interlibrary loan activity and number of subscriptions. Despite the increased number of periodical titles to which the libraries subscribe, the volume of interlibrary loan activity grew dramatically. In 1973/74 the mean total of interlibrary loan transactions, both borrowed and lent items, was 1,816. In 1988/89 the mean number was 4,748 , an increase of $161 \%$. It should be noted that the ratio of mean numbers of borrowed items to loaned items changed very little in the 15 -year period. Therefore, these college libraries continue to contribute to national resource sharing in the same proportion to their borrowing as they did 15 years ago.

This data suggests that the author's initial judgment based on personal experience was correct. Among this sample the college libraries were not effected in the same way by the escalating costs of periodicals as were large research libraries. However, the survcy results cannot be said to be representative of college libraries generally because of the nature of the sample group.The data suggest, however, that further research should be pursued to explore whether the findings of this study are true of a broader range of college libraries. Expanded findings which are broadly representative will confirm or refute the idea that college libraries have been able to adjust to increased costs of periodicals without cuts in the number of titles. Additional data might explore in more detail the issues touched on here. Two such issues are: What is the role of interlibrary loan in relation to periodical subscriptions and expenditures? How do increases in periodical budgets compare with other portions of college library benefits? Still other related questions were not even addressed here such as whether there were shifts in the titles subscribed to in response to financial pressures?

Given the lack of literature in this field there is considerable room for exploration of the topic of periodicals in college libraries.

\section{NOTES}

${ }^{1}$ The non-financial issues which confront college libraries with regard to periodicals which the author has identified are reviewed in "Periodicals Collections in College Libraries: Improving Relevancy, Access, Availability," Journal of Academic Librarianship 17 (November 1991): 298-301.
${ }^{2}$ Charles Hamaker, "Library Serials Budget: Publishers and the Twenty Percent Effect," Library Acquisitions: Practice and Theory 12 (1988): 211-19.

JJack A. Clarke, "The ACM Periodical Bank: A Retrospective View," College \& Research Libraries 41 (1980): 503-09; Blair Stewart, "Periodicals and the Liberal Arts College Library," College \& Research Libraries 36 (1975): 371-78.

${ }^{4}$ Larry Hardesty and Jamie Hastreiter, "Mathematics Periodicals in Selected Liberal Arts Colleges," Collection Building 9 (1988): 3-11; Jamie Webster Hastreiter, Larry Hardesty, and David Henderson, Periodicals in College Libraries (CLIP Note \#8) (Chicago: Association of College and Research Libraries, a division of the American Library Association, 1987); Tony Stankus and William C. Littlefield, "Meeting the Journal Needs of Small College Chemistry Departments," Science and Technology Libraries 8 (Spring 1988): 35-51; Theresa Taborsky and Patricia Lenkopwski, Collection Development Policies for College Libraries (CLIP Note \#11) (Chicago: Association of College and Research Libraries, a division of the American Library Association, 1989).

${ }^{5}$ Robert N. Broadus, "The Measurement of Periodicals Use," Serials Review 11 (1985): 57-61; Martin Gordon, "Periodicals Use at a Small College Library," Serials Librarian 6 (Summer 1982): 6373; K. Kanapasek and Nancy P. O'Brien, "Undergraduate Periodicals Usage: A Model of Measurement," Serials Librarian 9 (1982): 65-74; Rosalee McReynolds, "Limiting a Periodicals Collection in a College Library," Serials Librarian 9 (Winter 1984): 75-81; Blair Stewart, "Periodicals and the Liberal Arts College Library," College \& Research Libraries 36 (1975): 371-78.

${ }^{6}$ Mark Y. Herring, "King College Library: Online Databases vs. Hard Copy Subscriptions," Library Hi Tech 1 (1983): 63 -68; Blair Stewart, "Periodicals and the Liberal Arts College Library," College \& Research Libraries 36 (1975): 371-78.

\section{Share your opinion with $C d R L$ News readers}

Do you feel strongly about a particular issue and want to share your thoughts with a wider audience than just your colleagues down the hall? Now you have the opportunity to share your thoughts with a national audience. CURL News is looking for wellreasoned commentaries on issues of interest to academic and research librarians for its new column,"The Way I See It." Essays should be between 500-750 words and should be sent to "The Way I See It," CURL News, ACRL, 50E. Huron St., Chicago, IL 60611-2795; fax: 312-280-7663; e-mail: U38398@UICVM. 